\title{
La aventura tercermundista del cine mexicano. Producción fílmica y diplomacia latinoamericana, 1971-1976
}

\author{
The Third World Adventure of Mexican \\ Cinema. Film Production and Latin \\ American Diplomacy, 1971-1976
}

\author{
Israel Rodríguez \\ (D) https://orcid.org/0000-0003-3825-974X \\ Instituto de Investigaciones Históricas \\ Universidad Nacional Autónoma de México, México \\ israelrr@unam.mx
}

Resumen: Durante la primera mitad de los años setenta la industria cinematográfica mexicana se embarcó de manera decidida, junto con el régimen mexicano, en una impetuosa empresa por conquistar los principales foros y espacios del Tercer Mundo. Si en el terreno político el cumplimiento de este objetivo implicó una ardua labor diplomática, la incursión acelerada de México en el tercermundismo cinematográfico requirió también de una compleja estrategia de promoción y negociación con los representantes de las distintas cinematografías del movimiento tricontinental. El artículo presenta un primer acercamiento a esta historia del tercermundismo cinematográfico mexicano impulsado por el régimen de Luis Echeverría. Mediante el análisis de distintas fuentes (hemerográficas, documentales, orales y cinematográficas), y basándose en el estudio de dos casos específicos de colaboración

cómo cITAR: Rodríguez, I. (2021). La aventura tercermundista del cine mexicano. Producción fílmica y diplomacia latinoamericana, 1971-1976. Secuencia (111), e1951. DoI: https://doi.org/10.18234/secuencia. v0i111.1951

c) 98

Esta obra está protegida bajo una Licencia Creative Commons Atribución-NoComercial 4.0 Internacional. 
cinematográfica (Chile y Cuba), el texto intenta evaluar y mostrar lo que esta etapa significó para el cine mexicano, para el contenido de sus películas, para sus mercados y para la proyección internacional de sus obras. Como resultado, el texto muestra, por un lado, las vicisitudes y los debates a los que se enfrentó el cine mexicano en su camino por insertarse en un espacio político que le resultaba ajeno y, por otro, que el arduo trabajo emprendido desde 1971 por los funcionarios y cineastas mexicanos se tradujo hacia el final del sexenio echeverrista en un éxito, si no económico, sí político para el régimen que patrocinaba aquellos esfuerzos.

Palabras clave: cine mexicano; cine del Tercer Mundo; tercermundismo; Miguel Littín; Chile; Cuba; Rodolfo Echeverría; Pésaro.

Abstract: During the first half of the 1970s, the Mexican film industry, together with the Mexican regime, set out to conquer the main forums and spaces of the Third World. Whereas in the political field, the fulfillment of this objective entailed strenuous diplomatic efforts, Mexico's rapid incursion into cinematographic Third Worldism also required a complex strategy of promotion and negotiation with representatives of the various types of cinematography in the tricontinental movement. The article presents a first approach to this history of Mexican cinematographic Third Worldism promoted by the Luis Echeverría regime. Through the analysis of a range of sources (hemerographic, documentary, oral, and cinematographic), and based on the study of two specific cases of cinematographic collaboration (Chile and Cuba), the text attempts to assess and show what this stage meant for Mexican cinema, the contents of its films, its markets, and the international projection of their works. As a result, the text shows, on the one hand, the vicissitudes and debates Mexican cinema faced in its efforts to insert itself in a political space that was alien to it and, on the other, that the hard work undertaken since 1971 at the end of the Echeverría administration by Mexican officials and filmmakers translated into political rather than economic gains for the regime that sponsored those efforts.

Keywords: Mexican cinema; Third World cinema; third worldism; Miguel Littin; Chile; Cuba; Rodolfo Echeverría; Pésaro. 
Recibido: 31 de enero de 2021 Aceptado: 1 de junio de 2021

Publicado: 19 de octubre de 2021

\title{
INTRODUCCIÓN
}

\begin{abstract}
A unque es común escuchar o leer en los ámbitos cinematográficos o académicos la historia (generalmente la anécdota) de la incursión del cine mexicano en el tercermundismo durante el sexenio echeverrista, sigue pendiente en los estudios académicos y en la historia del cine mexicano una revisión seria y profunda de lo que esta nueva etapa significó para el cine mexicano, para el contenido de sus películas, para sus mercados y para la proyección internacional de sus obras. Además, la referencia común al tercermundismo del cine mexicano pocas veces ha llamado la atención sobre la forma efectiva en la que esta industria, cada vez más controlada por el Estado, se artículó con los intereses de las políticas exterior e interior del régimen, transformando con ello, no sólo sus temas, sino también su relación con otras cinematografías. Por ello, el presente artículo intenta ofrecer un primer acercamiento a este tema que nos permita comprender cómo fue y qué implicó la participación del cine mexicano en la amplia corriente del tercermundismo cinematográfico.

Incorporando información de diversas geografías y de ámbitos tan distintos como el cine y las relaciones diplomáticas, el presente texto muestra cómo el régimen mexicano y su industria fílmica requirieron de un arduo trabajo y de la inversión de amplios recursos para lograr ocupar un lugar dentro del cine del Tercer Mundo. Para lograr este acercamiento, se explica en primer lugar y de manera sintética cómo y por qué el gobierno echeverrista decidió sumarse de manera tan abierta al tercermundismo diplomático de la década de los setenta. A partir de textos de especialistas del momento y de estudios recientes, mostramos que la decisión mexicana no resulta sorprendente vista a la luz del contexto internacional y de las necesidades políticas internas del régimen priista. Los apartados segundo y tercero se concentran en analizar la forma en que la burocracia cinematográfica mexicana emprendió decididos acercamientos con dos de las cinematografías más importantes del cine del Tercer Mundo: Chile y Cuba. Con base en estos dos ejemplos, se intentan mostrar las dificultades y debates que trajo este acercamiento cinematográfico con el Tercer Mundo dentro y fuera del país. Finalmente, el texto muestra una revisión somera de las imágenes producidas a la luz de este impulso y
\end{abstract}


señala cómo la promoción de estas obras se tradujo en un éxito, si no económico, sí político para el cine mexicano y para el régimen que lo patrocinaba.

\section{EL TERCERMUNDISMO MEXICANO Y EL CINE DEL TERCER MUNDO}

Uno de los pocos acuerdos historiográficos sobre el Tercer Mundo es que, en sentido estricto, este sólo existió como proyecto político. La acuñación de este concepto, su éxito como etiqueta, su popularización global y su transformación y apropiación en países periféricos y en comunidades subalternas hacen evidente que la única historia verdaderamente común es la de una configuración académica cuya difusión fue tal que pronto se tradujo en prácticas políticas, diplomáticas, económicas y culturales en todo el mundo (Berger, 2004, pp. 9-39; Kalter, 2013, pp. 23-38; 2016, pp. 34-64).

Establecer una genealogía o una geografía clara que muestre la expansión de un concepto académico, la conformación de un bloque diplomático y el surgimiento de un amplio número de movimientos disidentes que se identificaban como parte de un proyecto común de liberación resulta difícil. La multiplicación de obras escritas tanto en las capitales europeas como en los países periféricos y la adopción del término por parte de regímenes de una ancha gama ideológica y por movimientos contraestatales en todo el mundo hicieron del tercermundismo un sujeto de mil rostros (Prashad, 2007, passim). Una de las caras más visibles del tercermundismo entre los años cincuenta y setenta fue la diplomática. Esas décadas vieron surgir y consolidarse un heterogéneo movimiento internacional en el que un amplio número de Estados, incluyendo al mexicano, acometieron en distintos momentos una batalla por reconfigurar el orden económico internacional con la esperanza de lograr una relación menos desigual entre las naciones más industrializadas y las que se presentaban como "en vías de desarrollo". En este lapso, en distintos foros internacionales se hizo evidente que al interior de este Movimiento de Países No Alineados coexistirían permanentemente diversas posturas: por un lado, se encontraban aquellos regímenes que defendían la neutralidad estricta dentro del conflicto bipolar; y, por otro, una más cercana al bloque comunista, que apuntalaba la necesidad de lograr por la vía revolucionaria la completa liberación de los países del Tercer Mundo. La primera postura, menos beligerante, se aglutinó en el llamado Grupo 77 que, fundado en 1964 durante 
la primera Conferencia de las Naciones Unidas sobre Comercio y Desarrollo (UNCTAD, por sus siglas en inglés), se enfocó principalmente en denunciar en los foros internacionales el deterioro de los términos de intercambio y las desventajas estructurales para los países del Tercer Mundo en el mercado mundial. La otra corriente, liderada por Cuba, se fortaleció durante la década de los sesenta y se consolidó con la realización, en enero de 1966, de la primera Conferencia Tricontinental de La Habana (Kalter, 2013).

De acuerdo con Berger (2004, pp. 11-19), si el tercermundismo diplomático de los años cincuenta-sesenta estuvo dominado fundamentalmente por las corrientes más moderadas y neutrales (los llamados "regímenes de Bandung de primera generación"), durante los años sesenta-setenta el protagonismo fue de los países de la llamada segunda generación, varios de ellos explícitamente socialistas tanto en sus discursos como en sus políticas internas de desarrollo económico. Gobiernos como los de Ahmed Ben Bella y Houari Boume-dienne en Argelia, Ho Chi Minh y Tôn Đức Thắng en Vietnam, Salvador Allende en Chile o Fidel Castro en Cuba impulsaron un tercermundismo más radical tanto en los foros diplomáticos como al interior de sus países. La Tricontinental de La Habana no sólo involucró a un mayor número de países al sumar representantes de Asia, África y Latinoamérica, sino que definió una agenda internacional antiimperialista mucho más explícita y llamó la atención sobre la importancia de Latinoamérica en el proceso de transformación mundial. Entre la celebración de esta conferencia y la reunión de Argel en 1973, Cuba, Chile y Argelia se convirtieron en los principales centros del tercermundismo estatal (Brands, 2010, pp. 119-150; Byrne, 2016, pp. 244-285; Harmer, 2013, pp. 20-48). Por ello, a principios de los setenta las relaciones diplomáticas y culturales con estos tres países resultaban fundamentales para los regímenes que, como el mexicano, decidieron sumarse al tercermundismo diplomático.

La incursión de México en la corriente tercermundista, revisada a la luz de la historia diplomática nacional, las transformaciones geopolíticas y económicas de los años sesenta y la estrategia de política interior del régimen echeverrista, resulta menos sorpresiva y atípica de lo que tradicionalmente se piensa. ${ }^{1}$ En términos generales, la reconfiguración política y económica internacional originada por la distensión entre los bloques capitalista y socialista,

${ }^{1}$ Para una visión general de este proceso, véanse Anguiano (1977, pp. 177-205); Brands (2008, pp. 105-138); Dullingham (2018, pp. 113-133); García Robles (1976, passim); Herrera y 
y el evidente impulso ganado durante los años sesenta por el bloque de países no alineados estableció, en principio, un escenario propicio para la diversificación de las relaciones internacionales mexicanas hacia finales de la década de los sesenta. Por otro lado, la terminación del acuerdo Bretton Woods y el consecuente abandono estadunidense de la paridad fija con el oro puso fin, en 1971, a una etapa de la economía internacional caracterizada por la expansión económica y la estabilidad de los precios, obligando a la mayoría de los países latinoamericanos a comenzar una verdadera carrera por ampliar sus vínculos comerciales para tratar de reducir la dependencia comercial hacia el poderoso país del norte (Márquez y Silva, 2014, pp. 154-159). Además, en lo que a política interna se refiere, el caso mexicano no fue el único en el que un gobierno se valió del discurso tercermundista y lo utilizó como base de un nacionalismo con el que intentaba fortalecer o restituir su hegemonía interna. Hacia finales de los sesenta y principios de los setenta, varios gobiernos latinoamericanos, como respuesta al inminente fin de la relación especial con Estados Unidos y ante la necesidad de legitimación de sus respectivos regímenes, decidieron embarcarse en una política exterior común que buscaba limitar el dominio de Washington sobre la región y ampliar sus relaciones comerciales con países y bloques que parecían vetados durante los años más rígidos de la guerra fría. Esta nueva política internacional fue compartida, en mayor o menor grado, por gobiernos provenientes de un amplio espectro ideológico. Participaron en él tanto las dictaduras militares de Onganía, en Argentina, y de Velasco Alvarado, en Perú, como los gobiernos civiles de Carlos Andrés Pérez, en Venezuela, y Luis Echeverría, en México, además de los gobiernos socialistas de Fidel Castro y Salvador Allende (Brands, 2008, pp. 105-138; 2010, pp. 119-150).

En ese contexto, la apuesta tercermundista mexicana no fue sorpresiva ni significó un fenómeno aislado. El cambio diplomático ocurrido durante la gestión de Echeverría fue produciéndose desde finales de los sesenta, cuando se hizo evidente que la balanza comercial deficitaria de México frente a Estados Unidos se había convertido en el punto débil de la economía nacional. En este proceso, 1971 se muestra como el punto de no retorno. Ese año, tras el anuncio del llamado "Nixon Shock" que impondría una sobretasa de $10 \%$ a todas las importaciones estadunidenses, el gobierno de Echeverría se enfrentó a la necesidad de diversificar rápidamente sus mercados y, consecuentemente,

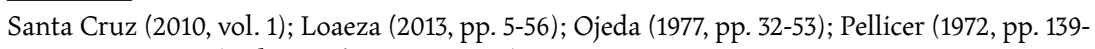
154; 1975, pp. 52-59); Shapira (1978, pp. 62-91). 
de cambiar la política exterior del país (Pellicer, 1972, 1975; Valero, 1972). A partir de ese momento la diplomacia mexicana se dirigió decididamente rumbo a la corriente tercermundista. Para septiembre del siguiente año, en su segundo informe de gobierno el presidente declaraba ya abiertamente que México se agruparía "activamente con el Tercer Mundo y, en especial [...], con los esfuerzos liberadores de América Latina” (Anguiano, 1977, p. 195). Como parte de esta nueva política, a partir de 1972 México amplió sus relaciones diplomáticas en Asia y África, comenzó un extenso programa de misiones comerciales y sustituyó a embajadores formados en la carrera diplomática o la política local por jóvenes economistas que tenían la misión de establecer o ampliar los lazos comerciales del país. Además, entre 1972 y noviembre de 1975, Echeverría hizo doce giras en las que visitó un amplio número de países en Asia y África, muchos de ellos, en palabras del último canciller de aquel gobierno, "lejanos a la realidad del viejo patrón de relaciones internacionales de México" (Ojeda, 2001, pp. 178-179).

Si bien la primera etapa de este cambio (1971-1972) se enfocó en la ampliación y diversificación de las relaciones diplomáticas, a partir de 1973 el discurso del régimen mexicano se cargó casi exclusivamente hacia el Tercer Mundo. En la retórica y en los hechos, el gobierno de Echeverría convirtió la necesidad de su inclusión dentro de este grupo en una verdadera obsesión. Una de las primeras y más sonadas acciones emprendidas por el gobierno mexicano fue su participación, en abril de 1972, en la III UNCTAD, celebrada en Santiago de Chile. Ahí, el presidente mexicano, además de mostrar su apoyo incondicional al gobierno de la Unidad Popular, presentó su famosa Carta de Derechos y Deberes Económicos de los Estados. Con menor revuelo dentro de la prensa local, pero de gran relevancia diplomática, fue la participación de México en la Conferencia de Naciones No Alineadas, celebrada en septiembre de 1973, en Argelia. A diferencia del fallido intento por participar en la cumbre de Belgrado más de una década atrás (Pettinà, 2015, pp. 752-764), la activa presencia de México en Argel pretendía manifestar abiertamente el compromiso del nuevo régimen con el Tercer Mundo. Al amparo de esta política, en los últimos años del sexenio echeverrista se multiplicaron conferencias, seminarios, reuniones políticas, competencias deportivas, festivales culturales $y$, por supuesto, semanas de cine y producciones fílmicas realizadas a la luz del nuevo tercermundismo mexicano. Como veremos a continuación, la industria cinematográfica mexicana, que experimentaba al mismo tiempo un importante proceso de intervención estatal y de control de sus contenidos 
por parte del régimen (Pelayo, 2016, pp. 317-340; Rodríguez, en prensa), participó activamente dentro de la política tercermundista del gobierno echeverrista. Acompañando los nuevos esfuerzos diplomáticos del régimen, el cine mexicano se esforzó también por hacerse de un vistoso lugar dentro del tercermundismo cinematográfico de los años setenta.

$\mathrm{Y}$ es que mientras el Tercer Mundo se consolidaba entre regímenes nacionales y entre grupos subalternos como un auténtico nuevo internacionalismo, el tercermundismo cinematográfico vivía también una etapa de gran efervescencia. Como ha estudiado ampliamente Mariano Mestman (2008; 2015; 2016; 2017), lo que durante los últimos años de la década de los sesenta se había presentado como intentos regionales de organización de distintas cinematografías, durante la primera mitad de los años setenta se tradujo en una verdadera apuesta tricontinental de organización fílmica asociada frecuentemente con los tiempos y los espacios de las principales reuniones de este movimiento internacional. Sin embargo, como ocurrió con el conjunto de manifestaciones políticas y culturales del tercermundismo, la historia del cine del Tercer Mundo difícilmente puede perfilarse como la de un movimiento unificado y coherente, con una geografía, una estética o un programa político definidos. Aunque entre 1973 y 1974 intentó articularse como un movimiento político internacional alrededor del Comité de Cine del Tercer Mundo (Mestman, 2017, pp. 75 y ss.), en general el tercermundismo cinematográfico se presentó como un cúmulo complejo de propuestas y experiencias político-cinematográficas que replicaban en muchos sentidos la diversidad propia del tercermundismo. En los puntos de encuentro que representaban los festivales de cine realizados en distintas ciudades latinoamericanas, africanas o europeas, se daban cita lo mismo colectivos radicales de cine revolucionario que consolidados cineastas de culto o representantes de industrias cinematográficas nacionales que, como la mexicana, intentaron participar en distintos momentos dentro del cine tricontinental.

De este modo, aunque existió desde los años setenta la tendencia a asimilar el cine tercermundista con los radicales planteamientos políticos del llamado Tercer Cine proyectado por los argentinos Fernando Solanas y Octavio Getino en $1969,{ }^{2}$ al lado de las propuestas de utilización del cine como

${ }^{2}$ Un análisis de estos planteamientos, véase en Valle (2012). Para una revisión del impacto del Tercer Cine en las prácticas cinematográficas y políticas a partir de su publicación, véase Willemen (1989). 
arma de liberación, un gran número de creadores, colectivos e industrias participaron del tercermundismo cinematográfico incluyendo temas o posturas políticas antiimperialistas en películas dirigidas a las elites intelectuales juveniles aficionadas al consumo del cine de autor o dentro de grandes producciones industriales realizadas dentro de los esquemas del cine hollywoodense (Robé, 2014, pp. 163-174). Por ello, el tercermundismo cinematográfico puede entenderse más como un punto de convergencia en el que la crítica generalizada al neocolonialismo se tradujo desde principios de los sesenta en espacios, propuestas y producciones fílmicas de todo tipo, desde filmes industriales de todos los géneros hasta obras marginales y militantes que acompañaban luchas de liberación. Como apuntó en su momento Alberto Elena (1993, pp. 21-22),

no parece oportuno concebir al cine del Tercer Mundo en oposición a la industria, puesto que en muchos casos la obra de importantes realizadores tuvo lugar en el seno de ésta, ni identificarlo con el cine militante, por un lado, o con subgéneros alienantes, por otro. En efecto, la vena revolucionaria de algunos exponentes del cine del Tercer Mundo -que sin duda han producido obras mayores- coexisten con producciones que aspiran a reproducir la estética hollywoodense.

Los cierto es que, aunque heterogéneo, hacia los años setenta el tercermundismo cinematográfico había generado una amplia comunidad internacional que tenía vistosos momentos de reunión en espacios como los encuentros del Nuevo Cine Latinoamericano o la Muestra de Pésaro. Como ha estudiado Mariano Mestman (2015; 2017), en los encuentros y festivales realizados en el contexto del tercermundismo cinematográfico, los proyectos de grupos subalternos herederos de los planteamientos de la nueva izquierda convivieron y se mezclaron (no sin conflicto) con poderosos proyectos oficiales que -como en Cuba, Chile, Argelia y, en su forma peculiar, México- intentaron orientar la transformación de sus industrias fílmicas nacionales para empatarlas con los lineamientos diplomáticos de los gobiernos que las sustentaban.

Hasta principios de los setenta la participación mexicana en estos espacios -los festivales de Viña del Mar (1967 y 1969), Mérida (1968), o la muestra anual realizada en Pésaro- había sido mínima y, en términos generales, 
poco afortunada. ${ }^{3}$ Sin embargo, en los siguientes años la situación cambiaría, aunque del modo quizá más inesperado. Como veremos ahora, si bien los cineastas independientes mexicanos habían sido los primeros en arribar tímidamente a estos espacios en los que se comenzaban a consolidar los movimientos del Nuevo Cine Latinoamericano y el Cine del Tercer Mundo, ${ }^{4}$ durante el gobierno de Luis Echeverría sería el Estado mexicano y su poderoso proyecto fílmico el que terminaría conquistando estos foros. Actuando por medio de sus embajadas, recibiendo a un sinfín de cineastas provenientes de las cinematografías latinoamericanas o africanas, organizando decenas de semanas de cine dentro y fuera del país y, por supuesto, produciendo obras en las que intentaba replicar el tercermundismo oficial, el cine industrial mexicano logró finalmente ocupar un lugar central en los espacios del cine del Tercer Mundo.

Como ocurría en el terreno de la diplomacia, en el que a principios de los setenta La Habana y Santiago ocupaban un lugar principal, en el ámbito del tercermundismo cinematográfico los cineastas cubanos y chilenos se encontraban entre las figuras más influyentes del cine latinoamericano y del cine del Tercer Mundo. Aunque el incipiente desarrollo de la industria cinematográfica chilena estaba aún lejos de la presencia internacional que para aquellos años alcanzaba ya el cine cubano, la acelerada transformación llevada adelante por Chile Films desde 1971 y la estrecha colaboración entre este y el Instituto Cubano de Artes e Industria Cinematográficos (ICAIC) ubicaron también al llamado Nuevo Cine Chileno en el centro de la escena. ${ }^{5}$ Por ello, no es de extrañar que, así como el proyecto tercermundista de Echeverría procuró las relaciones políticas con estos dos países, su programa fílmico priorizara también el acercamiento con estas dos cinematografías.

${ }_{3}^{3}$ Para muestra de ello, véase la vergonzante reseña que hace Jorge Ayala Blanco (1969, p. xv) de la participación mexicana en Viña del Mar en 1969.

4 Tanto Vázquez Mantecón (2016) como Mestman (2015) han rastreado la escasa participación de los cineastas mexicanos en los distintos encuentros realizados en América Latina.

${ }^{5}$ En agosto de 1971 y septiembre de 1972 Chile Films y el ICAIC firmaron importantes acuerdos de colaboración con la finalidad de profundizar en la búsqueda de identidades nacionales y detener la penetración cultural impuesta como resultado de la explotación neocolonial. "Convenio de colaboración Chile Films-ICAIc", exp. Chile. Cinemateca de Cuba, La Habana. Para una síntesis de la relación del ICAIc con la cinematografía de la Unidad Popular, véase Salazar Navarro (2020, pp. 176-182). 


\section{CHILE: CINE, EXILIO Y TERCERMUNDISMO}

Como es bien sabido, la incursión del gobierno mexicano en la corriente tercermundista y el acercamiento con el gobierno del presidente Allende ocurrieron de forma casi paralela. Al abierto posicionamiento de Echeverría al lado de las naciones del Tercer Mundo realizado en la asamblea de la onU en 1971, siguió el famoso viaje del mandatario mexicano a Santiago para participar en la III UNCTAD, en abril de 1972, y la no menos sonada -y polémica- visita del presidente chileno a México en noviembre-diciembre del mismo año. Como era de esperarse, el acercamiento con el país sudamericano tuvo una réplica casi inmediata en el ámbito cinematográfico. Además de la realización de las semanas de cine mexicano en Chile y de cine chileno en México que acompañaron a las visitas de los mandatarios, durante los dos años de acercamiento entre el régimen priista y la Unidad Popular el gobierno mexicano emprendió una intensa campaña cinematográfica con el fin de mostrar la cercanía entre el Estado mexicano y el gobierno de Allende.

Como parte de este proyecto, el oficialista Centro de Producción de Cortometrajes (CPC) realizó varios documentales con los que intentó transmitir a la opinión pública nacional e internacional la imagen de México y Chile como dos pueblos con un objetivo en común (Amaral de Aguiar, 2018, pp. 29-38). En obras como Compañero presidente (gira presidencial) (1972), Carta a una amiga (1972), Universidad comprometida (1973) y El viento de la historia (1973), el gobierno mexicano combinó de manera reiterada el discurso de amistad que unía a ambos pueblos con una cada vez más frecuente retórica latinoamericanista y antiimperialista. Compañero presidente (gira presidencial), por ejemplo, es el registro fílmico y la edición del discurso pronunciado por Echeverría en la III UNCTAD. La producción no tendría nada de excepcional si no fuera porque su realizador, el mexicano Servando González, decidió titular esta cinta (cuyo protagonista era Luis Echeverría) con la frase que identificaba popularmente a Salvador Allende y que, de hecho, había sido ya utilizada por el cineasta chileno Miguel Littín para nombrar la primera película de la Unidad Popular: Compañero presidente (1971).

Por su parte, Universidad comprometida, la cinta más conocida de esta serie, parece una muestra clara de la forma en que el régimen mexicano se valió de su acercamiento con el régimen socialista de Allende para reconfigurar su hegemonía entre los grupos de izquierda mexicanos. La cinta reproduce el famoso discurso que el presidente chileno pronunció frente a 
los jóvenes de la Universidad de Guadalajara. Sin embargo, de este discurso, el centro de producción mexicano eligió aquellos fragmentos en los que el mandatario aclara enérgicamente que la revolución no pasa por la universidad, que la revolución la hacen los obreros y los campesinos, y que el deber de los jóvenes es estudiar y servir al pueblo. La edición del CPC yuxtapone imágenes de masas empobrecidas u obreros organizados al lado de jóvenes médicos ayudando a los campesinos o disciplinados estudiantes universitarios preparándose para el futuro y engrosando los contingentes populares de los gobiernos progresistas. La potencialidad discursiva del presidente Allende parece inundarlo todo y fundir intencionalmente el proceso revolucionario chileno con las instituciones oficiales y los jóvenes mexicanos, con los burócratas aplaudiendo el discurso y con las masas de ambos pueblos marchando en las avenidas.

La trascendencia del filme, como se comprueba incluso en sus ecos actuales, es innegable. De ella se hicieron innumerables copias que fueron expuestas tanto en territorio mexicano como en las semanas de cine mexicano realizadas en varias partes del mundo. En el interior del país, ese discurso, su filmación, edición y amplia distribución se inscribieron sin duda en el intento echeverrista por contrarrestar el activismo estudiantil -apoderándose de ély por asimilar discursiva y visualmente al régimen mexicano con el gobierno socialista de Allende, cuya imagen de progresismo se convertía dentro de la película en un llamado a la disciplina y la unión nacional contra ese enemigo externo que era el imperialismo. El objetivo final era "legitimar internamente, ante los grupos de izquierda, la política de apertura democrática mediante la sanción de parte de un viejo líder de tanto prestigio entre las corrientes progresistas internacionales" (Ojeda, 2001, p. 179).

Pero, si el acercamiento entre los dos países había dejado su marca en las producciones del CPC, el golpe de Estado que segó la vida de Allende y la consecuente recepción de asilados chilenos en México resultaría determinante dentro del proyecto político y cinematográfico de los Echeverría. Como es sabido, tras el golpe militar que terminó con el gobierno de la Unidad Popular, la condena al gobierno de Pinochet fue inmediata y colocó al gobierno mexicano como uno de los principales defensores de la izquierda latinoamericana. En el ámbito cinematográfico, el arribo a territorio mexicano de varios cineastas cercanos al gobierno de Allende se promocionó ampliamente en los medios como un ejemplo de esa solidaridad internacional. 
Sin embargo, aunque el exilio chileno ocupó un lugar importante en la prensa y la memoria histórica de las relaciones bilaterales, la política de refugio del gobierno mexicano en el caso del cine y en la mayoría de los ámbitos fue más bien selectiva (Díaz Prieto, 1998, pp. 66-67; 2010; Rojas Mira, 2016, p. 124). A pesar del exaltado apoyo diplomático ofrecido por México, de los cineastas que se exiliaron tras el golpe de Estado pocos se quedaron en México. Tras algunos meses de difícil situación laboral, la mayoría decidió emigrar, como el director Orlando Lübbert o el camarógrafo Hernán Morris, quienes rápidamente emigraron a Alemania y Canadá, respectivamente. En entrevista, el primero recuerda que "a Littín el presidente Echeverría lo instaló cerca de Churubusco y le arreglaron la existencia. Para mí era comenzar de cero porque nunca me arrimé al poder. En realidad, el pasaporte mexicano que me dieron era muy precario y sólo tenía vigencia por tres meses. Para muchos fue así la situación". ${ }^{6}$

El caso de Miguel Littín al que se refiere Lübbert fue totalmente distinto y para nuestro estudio resulta paradigmático. ${ }^{7}$ Para 1973 Littín ya era una de las cabezas más visibles del ascendente movimiento del Nuevo Cine Latinoamericano y de los foros del cine del Tercer Mundo. Quizá por ello, tras algunos días en la embajada mexicana, su solicitud de visa para refugiarse en México se aprobó con pocos inconvenientes. ${ }^{8}$ La periodista chilena Faride Zerán Chelec anota que: "sin duda, detrás [de su aceptación] había un grupo de amigos que lo ayudaba. Ellos habían efectuado los contactos previos con funcionarios de la representación Azteca para que Miguel Littín y su hermano Hernán pudieran ingresar sin problemas" (Sousa de Silva, 2015, p. 49). Además, como ha señalado Sousa de Silva (2015, p. 51), el cineasta chileno adquirió de inmediato una posición estable y un círculo social en el que figuraban los principales representantes del cine mexicano, tanto de la generación

${ }^{6}$ Entrevista de Israel Rodríguez a Orlando Lübbert, México-Santiago, 8 de agosto de 2019. La documentación sobre el proceso de refugio en la embajada mexicana y sobre el posterior traslado a México de los cineastas Álvaro Covacevich, Orlando Lübbert, Hernan Morris y Miguel Littín fue donado por la embajada mexicana al Museo de la Memoria y los Derechos Humanos, en Santiago de Chile, donde pude revisarlo.

${ }^{7}$ Para una revisión amplia del itinerario estético y político de Miguel Littín en México, véanse Sousa de Silva (2015) y Rodríguez (2020).

${ }^{8}$ La información sobre la estancia de Littín en la embajada mexicana y el otorgamiento de la visa por parte del gobierno mexicano se encuentra en el acervo de la embajada de México, Museo de la Memoria y los Derechos Humanos, Santiago de Chile. Véase también Rodríguez (2020). 
echeverrista como de personajes emblemáticos de la época de oro, como Emilio El indio Fernández o Luis Buñuel. En esas favorables circunstancias, la filmación de la cinta Actas de Marusia se convertiría pronto en una oportunidad de éxito tanto para el cineasta exiliado como para el proyecto tercermundista del cine mexicano.

Littín había llegado México con un proyecto concreto: la filmación de un texto inédito de Patricio Manns que había leído en La Habana. Publicada dos décadas más tarde, la novela Actas de Marusia combinaba dos hechos históricos ocurridos en el norte de Chile: la matanza de trabajadores salitreros cometida por el ejército chileno el 21 de diciembre de 1907 en la escuela del pequeño pueblo de Santa María de Iquique, y la llamada masacre de Marusia, acaecida en ese pueblo en marzo de 1925 como respuesta del gobierno de Arturo Alessandri a una huelga de los trabajadores de una mina de salitre. En la narración, el asesinato inicial de un ingeniero de minas estadunidense inaugura una serie de venganzas mortales entre empleados y representantes de la empresa. El Estado chileno, por medio del ejército, interviene en favor de los capitalistas extranjeros para tratar de dar por terminado el conflicto. Sin embargo, esto sólo incrementa la furia de unos trabajadores cada vez más politizados. La historia termina trágicamente con el asesinato de todos los pobladores a manos del Estado. Obviamente, la obra resultó enormemente atractiva para el cineasta chileno, pues mediante la resignificación de este hecho histórico podía denunciar el golpe militar que lo había expulsado de su país. "Pensaba que una película sobre el golpe militar -exponía Littín- podría caer fácilmente en lo anecdótico. En cambio, si tomaba un episodio de la lucha de clases de Chile y del continente, me era posible llegar más a lo conceptual."

Su proyecto fue aceptado y financiado por el oficialista Banco Nacional Cinematográfico (BNC), que durante el proceso de producción no escatimó en gastos. A solicitud del director se trajo al reconocido actor italiano Gian Maria Volonté para el papel principal y se pidió que el famoso sonidista Mikis Theodorakis musicalizara la cinta. El BNC registró en su último informe que el filme costó más de 17000000 de pesos, una cifra sin duda elevada si se toma en consideración que una producción también exitosa como Canoa había costado ese mismo año poco más de 5000000 (Echeverría, 1976, p. 57). Además, este financiamiento resultaba claramente desproporcionado si se tomaba en

9 “Miguel Littín afirma que perdió en Cannes por un voto”, Excélsior, 18 de junio de 1976. Centro de Documentación de la Cineteca Nacional, México. 
cuenta no sólo la corta trayectoria de Littín, sino el carácter poco comercial de sus obras anteriores que, aunque famosas en los círculos intelectuales, no habían sido éxitos en taquilla.

La tarea nada sencilla de filmar a Chile en México fue sin duda el principal mérito de Littín. Sin embargo, de esta condición se desprende uno de los elementos más visibles de la película: la marcada intención de mostrar el levantamiento de los obreros salitreros del norte de Chile como una etapa de la larga lucha internacional contra el despojo imperialista. Este aspecto resulta aun más claro si se analiza a la luz de la película inmediatamente anterior de este director, La tierra prometida (1972), en la que se narraba la experiencia de una pequeña comunidad del sur chileno durante la breve república socialista de Marmaduke Grove. Tanto en esa obra como en constantes intervenciones públicas, el cineasta había manifestado su pretensión de hacer un cine que se apropiara de los mitos nacionales chilenos y los resignificara dentro de la lucha contemporánea de liberación. ${ }^{10}$

En Actas de Marusia la intención no sólo es distinta, sino completamente opuesta. Chile parece desdibujarse intencionalmente en la cinta para dar lugar a una lucha mundial, casi esquemática, entre explotados y explotadores, entre colonizadores y colonizados. Sin duda las condiciones abonan en este sentido: la necesidad de filmar la lucha del salitre chileno en una mina de Chihuahua o de sustituir a los trabajadores andinos por mexicanos obligaba a no acentuar un contexto chileno que no podía ilustrarse fácilmente. Sin embargo, en el filme el discurso nacionalista de Littín ha desaparecido casi por completo. En la película poco importaba que los obreros de principios de siglo reprodujeran la retórica tercermundista de los años setenta: más que buscar la fidelidad histórica o el llamado nacionalista, Littín pretendía la alegoría internacionalista que por aquellos años repetía incansablemente el tercermundismo mexicano.

A juzgar por las notas de prensa y por las entrevistas a los funcionarios del cine mexicano, para el gobierno echeverrista la filmación de la película era sólo el inicio de un amplio proyecto que tenía como objetivo principal la promoción mundial de la cinta como una obra maestra del cine tercermundista. Tras su conclusión, el aparato gubernamental mexicano inició una intensa

10 Para una revisión del nacionalismo de Littín antes de su llegada a México, véase Rodríguez (2020). Los planteamientos nacionalistas de Littín dentro del Manifiesto Político de los Cineastas Chilenos, en Barría (2011, p. 47). 
campaña gracias a la cual logró que la cinta de Littín se convirtiera entre 1975 y 1976 en una de las cintas protagónicas del cine en todo el mundo: en 1976 Actas de Marusia compitió por el Óscar en la categoría de mejor película extranjera y por la palma de oro en el Festival de Cannes, e inauguró ese mismo año la Muestra de Pésaro, el principal punto de encuentro del movimiento de cine del Tercer Mundo.

Sin embargo, en México la recepción y la crítica de Actas de Marusia fueron de las más polémicas en la historia del cine mexicano. Tras su estreno, críticos consolidados, intelectuales y público general engrosaron las secciones de opinión para valorar, alabar o denostar la cinta. Las opiniones no parecían admitir medias tintas ni interesarse sólo por los aspectos cinematográficos. El acalorado debate se mantuvo siempre en el terreno de las opiniones políticas que exaltaban o denunciaban el fervor latinoamericanista del director y del gobierno que lo patrocinaba: "cine popular desde sus raíces", "arte genuinamente popular", "muestra de la madurez ideológica de su director", ${ }_{11}$ eran las frases con las que se elogiaba la película. En el lado opuesto se encontraban quienes no compartían el entusiasmo tercermundista de la prensa oficial y que, con el crítico Jorge Ayala Blanco a la cabeza, señalaban a la cinta como el más claro ejemplo "de todos los errores en que suele incurrir el cine de izquierda industrializado y el naciente 'cine del Tercer Mundo dentro del sistema" (Ayala Blanco, 1976, p. xvi).

Y es que en México fueron muchos los que no vieron con buenos ojos el apoyo otorgado al cineasta chileno. Desde la izquierda, el mismo Ayala Blanco (1986, pp. 234-235) se burlaba de que el BNC ahora financiara "la obra maestra del cine del Tercer Mundo", cuya realización respondía a la "impaciencia del oportunista director chileno Miguel Littín: a punto de acceder al big business internacional de izquierda". Desde una posición distinta, mucho más a la derecha, el polémico Manuel Ávila Camacho López publicó una declaración en el periódico Excélsior en la que acusaba a Littín de "héroe autoasumido y salvador del cine mexicano", que vivía exprimiendo al erario a través del BNC aprovechándose de la retórica populista del nuevo régimen. ${ }^{12}$

Más allá de la polémica -que se repitió varias veces durante la estancia de Littín en México-, lo que interesa destacar es que, a partir de su vinculación con el aparato cultural mexicano, el director chileno tuvo que elaborar

\footnotetext{
${ }^{11}$ "Actas de Marusia: la posibilidad de un cine popular", Otro Cine, núm. 1, enero de 1975.

12 “Ávila Camacho acusa a Littín”, Excélsior, 12 de octubre de 1976.
} 
una compleja retórica para evadir la crítica interna que lo tachaba, desde la derecha, de tercermundista aprovechado y, desde la izquierda, de justificador del régimen. De acuerdo con Sousa de Silva (2015, p. 77), tras la nominación al Óscar, Littín tuvo que navegar con dificultad en los foros del cine tercermundista para sostener que seguía haciendo un cine antiimperialista y revolucionario, aunque lo realizara dentro de una estructura de producción burguesa y cobijado por un Estado autoritario.

En el ámbito nacional ocurría lo mismo. Desde su llegada al país, pero sobre todo desde que Actas de Marusia compitió como mejor película extranjera en los premios Óscar y por la Palma de Oro en el Festival de Cannes, Littín navegó hábilmente entre su militancia política y su cercanía con el régimen mexicano. En los principales foros internacionales habitualmente repetía que la cinta era parte de la nueva etapa universal del cine chileno y que las nominaciones eran una victoria de la resistencia en el exilio. Pero, por otra parte, en sus entrevistas en México se esforzaba por recalcar que era un logro del nuevo cine mexicano y que, a pesar de la trascendencia de aquellos premios, para él era mucho más importante ganar un Ariel y ser reconocido por el cine mexicano. ${ }^{13}$

Lo cierto es que el éxito de esta cinta fue, sin duda, un triunfo para todo mundo: por un lado, Littín había obtenido del Estado mexicano apoyo económico, logístico y propagandístico para realizar su película y con ello posicionarse en los principales espacios del cine mundial; por el otro, el Estado mexicano manifestaba al ámbito internacional su posición ideológica al patrocinar a este cineasta exiliado y al realizar una megaproducción tercermundista en suelo mexicano que, además, se convertía en un innegable éxito internacional.

\section{CUBA: COLABORACIÓN CINEMATOGRÁFICA Y VIGILANCIA}

Si bien durante la primera mitad del sexenio echeverrista las relaciones con Chile ocuparon un lugar principal, el trágico final del gobierno de Allende hizo necesario centrarse en una nueva fuente externa de legitimidad política.

13 "Littín le concede más valor al Ariel del cine mexicano que al Oscar", Excélsior, 10 de abril de 1976. 
Por ello, durante la segunda parte de su mandato, el régimen de Echeverría empezó a cultivar y promover nuevas relaciones con otros gobiernos progresistas. "Dados los constreñimientos comprensibles que limitaban sus interacciones con los regímenes militares en el hemisferio occidental, las únicas posibilidades disponibles para desarrollar nuevas alianzas nacionalistas-izquierdistas se encontraron con los gobiernos de Venezuela y Cuba" (Shapira, 1978, p. 73). Sin embargo, tras una década de altibajos y tensiones, para principios de los setenta las relaciones entre el gobierno mexicano y la revolución cubana se encontraban en uno de sus puntos más bajos y sólo el importante interés mutuo y un arduo trabajo diplomático lograrían restituir (al menos en apariencia) el ambiente de confianza entre ambas naciones.

Como es bien sabido, México no sólo fue uno de los pocos países que mantuvieron, al menos formalmente, relaciones diplomáticas y comerciales con el gobierno de Castro, sino que se convirtió en uno de los principales soportes regionales del régimen cubano. Sin embargo, durante los gobiernos de López Mateos y, sobre todo, Díaz Ordaz, la declarada amistad entre ambos gobiernos fue más simbólica que efectiva. La tradicional ambigüedad del Estado mexicano, aliado indiscutible de Estados Unidos, y el decidido apoyo del gobierno cubano a los grupos guerrilleros latinoamericanos hasta, por lo menos, 1967, dieron como resultado en los años más álgidos de la guerra fría una relación de mutua desconfianza (Keller, 2015, p. 233). Además, hay que recordar que, durante la paranoica gestión de Díaz Ordaz, la clara identificación del proceso revolucionario cubano con los nacientes grupos guerrilleros en México, así como la simpatía que el levantamiento cubano despertaba entre los jóvenes universitarios protagonistas del movimiento estudiantil de 1968, imprimieron un sello de desconfianza del gobierno mexicano hacia su contraparte cubana (Keller, 2015, pp. 198-200; Lajous, 2012, p. 226).

Sin embargo, las nuevas circunstancias en ambos países parecían propicias para dejar esa etapa atrás. Por un lado, como ya anotamos, el régimen mexicano, ante la caída del gobierno de Allende y la proliferación de dictaduras conservadoras en el resto de Sudamérica, vio en el fortalecimiento de su relación con Cuba una excelente oportunidad para actualizar el carácter social y ahora tercermundista de la revolución mexicana. Por el otro lado, como demostró Harmer (2013, pp. 61-64, 84; véase también Wright, 2018, pp. 112 y ss.), desde finales de los sesenta, tras la muerte del Che Guevara en Bolivia y el fracaso de los movimientos armados en casi todos los países de Latinoamérica, el régimen cubano, alineado fuertemente a los intereses 
soviéticos, abandonó casi por completo su política de revolución permanente y echó a andar un fuerte intento por estrechar sus relaciones diplomáticas y comerciales con los gobiernos latinoamericanos. En este nuevo contexto, el fortalecimiento de las relaciones cubano-mexicanas representaba una ganancia para ambos gobiernos. Sin embargo, como veremos con la revisión del acercamiento cinematográfico entre estos dos países, la nueva etapa diplomática estaba aún lejos de dejar atrás las prácticas de desconfianza mutua.

Para principios de los setenta, la importancia de Cuba en el terreno tanto geopolítico como cinematográfico resultaba indiscutible. Como mostró recientemente Salazar Navarro (2020, pp. 127-220), desde la década de los sesenta el ICAIC se había convertido en uno de los epicentros del cine latinoamericano y del movimiento del cine del Tercer Mundo. Para principios de los setenta, en los espacios de este movimiento mundial el protagonismo de figuras como Julio García Espinosa y, sobre todo, Alfredo Guevara era ya indiscutible. Por ello, si una industria quería posicionarse en estos foros, granjearse el favor del IcAic parecía una tarea obligada.

El 24 de junio de 1974, en el aeropuerto internacional José Martí, en La Habana, un grupo de altos funcionarios, entre ellos Víctor Alfonso Maldonado, embajador de México en La Habana; Jorge Reyes, embajador cubano en México, y Alfredo Guevara, director del ICAIC, esperaba la llegada de una importante delegación mexicana. Esta, sin embargo, no estaba constituida por diplomáticos, ministros o ingenieros. En el pequeño MiG que arribó aquella tarde viajaba una comitiva encabezada por Rodolfo Echeverría (hermano del presidente mexicano y director del Banco Nacional Cinematográfico), Maximiliano Vega Tato (gerente general de la productora estatal ConAcine) y el director de cine Gonzalo Martínez. ${ }^{14}$ La visita de los mexicanos inauguró una etapa de por lo menos dos años en la que el cine fue utilizado para promover y enfatizar el nuevo acercamiento bilateral. Durante dicha etapa se sucedieron uno tras otro los viajes de mexicanos a Cuba y de cubanos a México, se organizaron semanas para proyectar las producciones más recientes de ambas cinematografías y, finalmente, se logró la firma de importantes acuerdos de colaboración y coproducción.

El objetivo principal de la presencia de los mexicanos en la isla, según se dijo, era la organización de dos semanas de cine: una de obras cubanas que

14 "Llegó la delegación mexicana", Juventud Rebelde, 28 de junio de 1974; Martha D. Solís, "Rodolfo Echeverría viaja a Cuba para proyectar el Cine mexicano", Siempre!, 24 de julio de 1974. 
se llevaría a México, y otra de cintas mexicanas que se proyectaría en Cuba. Estos eventos, al parecer, no fueron detallados durante esa primera visita $y$, en consecuencia, tuvieron que planearse a la distancia. La correspondencia entre Rodolfo Echeverría y Alfredo Guevara sobre el tema es abundante y se conserva aún en la Cinemateca de Cuba. En el intercambio, ambos funcionarios precisan fechas, acuerdan espacios y negocian el material que se exhibirá en cada evento. Sin embargo, según se observa en las cartas, este último punto era un tema delicado y requirió de varias comunicaciones antes de quedar afinado. ${ }^{15}$

La lista de cintas mexicanas propuesta por Echeverría, como era de suponerse, incluía, además de una selección de cortometrajes del CPC sobre los logros del Estado mexicano y la actividad internacional de Luis Echeverría, una selección de las cintas más exitosas del nuevo modelo de "apertura cinematográfica" mexicana: ${ }^{16}$ Aquellos años (1973), El principio (1973), El castillo de la pureza (1972), Orozco, en busca de un muro (1974), El rincón de las vírgenes (1972), Fe, esperanza y caridad (1974), Mecánica nacional (1972) y Calzonzin inspector (1972). Sin embargo, la propuesta de Echeverría encendió pronto las alertas de los funcionarios cubanos que, al ver las obras producidas por la cinematografía mexicana, comenzaron un debate sobre la pertinencia de proyectar ante el público cubano las películas del llamado "nuevo cine mexicano" que, como sabemos, destacaban por haberse realizado en un ambiente de relajación de la censura no sólo política, sino sobre todo moral y sexual.

Tras revisar el material enviado por México, en documentos con anotaciones a mano y correcciones continuas se aprecia cómo Pastor Vega, Julio García Espinosa y Alfredo Guevara criticaron duramente el contenido del cine mexicano y comunicaron los cambios que serían necesarios antes de exhibir las cintas. De Fe, esperanza y caridad, por ejemplo, sólo el último de los cortometrajes - un fuerte cuestionamiento a la caridad burguesa como generadora de desgracias- salió bien librado. El resto de las obras que componen esta cinta (en las que aparecen escenas de violaciones múltiples y un buen número de palabras altisonantes) fueron catalogadas de vulgares o directamente reaccionarias. ${ }^{17}$ Del mismo modo, en cintas como El principio, Mecánica

${ }^{15}$ Correspondencia entre Rodolfo Echeverría y Alfredo Guevara, 6 de julio-20 de septiembre de 1974. Cinemateca de Cuba, La Habana.

${ }^{16}$ Para una revisión amplia de las propuestas y resultados de la política de apertura cinematográfica, véase Costa (1998).

${ }_{17}$ Selección de filmes para la semana de cine mexicano en Cuba. Cinemateca de Cuba, La Habana. 
Nacional o Los días del amor, los censores cubanos pedían suprimir secuencias violentas, imágenes de masturbaciones o diálogos "reaccionarios". Respecto a los materiales del CPC en los que se promocionaba la labor del Estado mexicano, una nota a mano que no aparece en la versión final del documento señalaba abiertamente que no se debía proyectar al pueblo de Cuba material promocional del gobierno mexicano. En todo caso, sentenciaba la nota, podía incluirse Universidad comprometida, "y sólo porque es la filmación del discurso de Allende en Guadalajara".

Y es que, como han explicado García Borrero (2008) y Salazar Navarro (2020, passim), estas acciones de censura no ocurrían en un ambiente aislado. El periodo comprendido entre 1971 y 1976, conocido popularmente como el quinquenio gris, fue uno de los más restrictivos para el cine $-y$ el conjunto de la producción intelectual de la isla- en lo que a censura se refiere. Aunque durante los años sesenta el fenómeno de revolución y modernización de la cinematografía mundial coincidió y convivió con el proceso de revolución política y social de la isla, durante la década siguiente, pese a la oposición de Guevara, el ICAIc finalmente fue absorbido por el tristemente célebre Ministerio de Cultura, organismo de vigilancia encargado de supervisar el contenido de la producción artística y cultural del país. Como resultado, tanto la producción fílmica del Instituto como el cine extranjero que se exhibía en la isla fueron sometidos a una vigilancia cada vez más estricta para impedir la proyección al público cubano de imágenes inmorales o desviaciones ideológicas (García Borrero, 2008, pp. 76-77).

Es cierto que durante los años más duros de la restricción fílmica el público cubano se refugió por lo regular en las principales películas de la época de oro del cine mexicano que, con ciertas mutilaciones, nunca dejaron de proyectarse, pues resultaban inofensivas pese a su carácter capitalista y contenían frecuentemente un discurso moralizador que debía resultar atractivo para el gobierno de la isla (Vega et al. 2007). Sin embargo, en este nuevo periodo de acercamiento cinematográfico, el Estado mexicano no estaba interesado en promover aquellas obras, sino en presumir el nuevo cine mexicano como símbolo de libertad creadora y apertura. El problema era que aquellas cintas estaban llenas de escenas, groserías e ideas que resultaban problemáticas en la Cuba del quinquenio gris y que, por lo tanto, de formas más o menos veladas, debieron censurarse. Al final, la Semana del Cine Mexicano se realizó y, según la prensa oficialista, fue todo un éxito. En pos de un repetido deseo de estrechar los lazos de colaboración, el IcAIc proyectó las reac- 
cionarias cintas mexicanas y el BNC debió aceptar en Cuba una censura que, aseguraba, no se ejercía en México. Sin embargo, la desconfianza entre estos regímenes era mutua y, si la organización de la semana de cine mexicano había puesto a prueba la tolerancia de los censores cubanos, la realización de la semana de cine cubano también pondría a trabajar a los sistemas de vigilancia mexicanos.

Del mismo modo en que el cine mexicano resultaba habitual para el público cubano, la Semana del Cine Cubano en México no vino a descubrir nada nuevo para los universitarios e intelectuales mexicanos a quienes estaba dirigida. Como hicieron notar en su momento los críticos de cine, lo único que hizo el esfuerzo cultural y diplomático fue sacar a las producciones cubanas del circuito de cineclubes universitarios y proyectarlas en las salas comerciales. Aun así, las funciones fueron todo un acontecimiento y la asistencia resultó absolutamente masiva (Pérez Turrent, 1974, p. 50). ${ }^{18}$

Como había ocurrido meses antes en La Habana, para la Semana de Cine Mexicano una comisión de importantes figuras de la industria cubana visitó México entre el 7 y el 18 de octubre de 1974 y estuvieron presentes en la inauguración y clausura de la mencionada semana en la recién estrenada Cineteca Nacional..$^{19}$ Como puede apreciarse en las notas que acapararon las secciones de cine de la prensa mexicana, en aquellos eventos, tanto los funcionarios mexicanos (Hiram García Borja, director de Cinematografía, y Salvador Robles Quintero, gerente del BNC) como los invitados cubanos (Santiago Álvarez y Julio García Espinosa) elaboraron complejas retóricas para enfatizar los intereses comunes de estas cinematografías mientras se dejaban en claro y se justificaban las evidentes diferencias políticas y estéticas. Robles Quintero, por ejemplo, señalaba que,

aunque ambos tienden a la descolonización cultural y al rescate de las pantallas latinoamericanas para proyectar los verdaderos problemas de nuestros pueblos [...], la renovación del cine mexicano no se hace a partir de una revolución socialista. La comparación entre el cine mexicano y el cine cubano debe partir de este hecho: los cubanos liquidaron totalmente la vieja industria cine-

${ }^{18}$ Tomás Pérez Turrent, "La semana del cine cubano", Sucesos para Todos, 2165, 30 de noviembre de 1974.

${ }^{19}$ Itinerario de la delegación cubana en México, exp. Semana del cine cubano en México. Cinemateca de Cuba, La Habana. 
matográfica, en cambio, la mexicana [...] está intentando construir una nueva etapa sin liquidar los moldes anteriores. ${ }^{20}$

Por su parte, Santiago Álvarez, aunque dedicó buena parte de su intervención a señalar las diferencias de ambas cinematografías, concluyó su discurso, seguramente para beneplácito de los funcionarios mexicanos, acentuando la lucha común que, gracias al nuevo impulso mexicano, llevaban adelante los dos pueblos que desde ese momento apostaban "por un cine de sana alegría que se enfrente al enmascaramiento ideológico de los pueblos. Por un cine antiimperialista, antiamericanista y libre." ${ }^{21}$

Hasta este punto, la visita tenía poco de excepcional. Antes y después de la Semana de Cine Cubano, en México se hicieron múltiples eventos similares con las cinematografías de los países africanos, asiáticos, latinoamericanos o de Europa del Este con los que el gobierno de México intentaba estrechar lazos. Sin embargo, la amplia documentación existente nos permite observar, por un lado, la importancia que el gobierno mexicano otorgó a este evento, y por el otro, que el Estado mexicano no dudó en vigilar cuidadosamente el interés que el discurso y la presencia cubana pudieran despertar entre los jóvenes mexicanos. Si hoy es posible saber con exactitud la cantidad de personas asistentes a cada una de las funciones, la procedencia de muchos de ellos y en algunos casos sus nombres, es porque la Dirección Federal de Seguridad designó a un grupo de agentes para que asistiera e informara todo lo ocurrido en el evento. Gracias a los reportes de los espías mexicanos sabemos, por ejemplo, que en las proyecciones en el Cine Regis -la otra sede del evento- se ocuparon todas las 620 butacas y que aproximadamente $90 \%$ del público era de jóvenes universitarios. ${ }^{22}$ Los agentes, que a juzgar por sus informes parecían disfrutar bastante las cintas cubanas, detallaban la cantidad de elementos desplegados en el evento y la forma en la que se infiltraban entre el público estudiantil y consignaban nombres importantes, como los de

20 "Habla Robles Quintero. Descolonización cultural, meta del cine mexicano y del cine cubano”, El Día, 26 de septiembre de 1974.

${ }_{21}$ "El cine, la expresión más lograda por la revolución cubana: Robles Quintero”, El Día, 12 de octubre de 1974.

${ }^{22}$ Dirección General de Investigaciones Políticas y Sociales-Dirección Federal de Seguridad (en adelante DGIPS-DFs), caja 1159 B, exp. 3, Archivo General de la Nación (en adelante AGN), México. 
Eduardo Ibarra Aguirre y Alba Martínez, yerno e hija de Arnoldo Martínez Verdugo, primer secretario del Partido Comunista Mexicano. ${ }^{23}$

Pero, como había ocurrido en La Habana, entre desconfianza, vigilancia y censura, los funcionarios de ambos países declararon al final que las semanas de cine habían sido un ejemplo de la hermandad entre los pueblos y aseguraron que los lazos de colaboración seguirían estrechándose. Como sabemos, tras un lento pero constante acercamiento, en 1975 Fidel Castro viajó a México y Luis Echeverría voló a La Habana para cerrar un largo y fructífero proceso diplomático. Del mismo modo, la labor de Rodolfo Echeverría en este sentido puede calificarse como exitosa. En 1976, tras una larga negociación, el ICAIC y el BNC firmaron un amplio acuerdo de colaboración que incluía el apoyo técnico por parte de los mexicanos para impulsar las producciones cubanas y la ayuda del ICAIC para lograr un aumento en la calidad de los productos del CPC. Además, el ICAIC abandonaba su estricta política de no participar en coproducciones -lo que quizá representaba el principal logro para los mexicanos- y aceptaba realizar dos cintas con el gobierno mexicano con las que se promovería "la afirmación de la identidad latinoamericana". ${ }^{24}$

\section{POSTALES DE UN BREVE E INTENSO TERCERMUNDISMO}

En 1972 se cumplieron 100 años de la muerte del Benemérito de las Américas, figura clave en el imaginario del régimen priista. Como era de esperarse, entre las múltiples acciones para conmemorar al héroe nacional se contempló una superproducción cinematográfica. La cinta, que al final llevó el título Aquellos años (Felipe Cazals, 1973), tiene poco de excepcional. Durante algo más de hora y media la versión oficial de la historia patria, con su enfoque maniqueo, sus figuras de bronce y sus diálogos para la posteridad es condensada con dificultad en la pantalla. Sin embargo, un elemento llamó la atención desde sus primeras proyecciones y la volvió tristemente célebre en la historia del cine mexicano. Al final de la película, con el ejército inva-

${ }^{23}$ DGIPS-DFs, caja 2732, exp. único; caja 1756B, exp. 6, fs. 66, 68-69, 70-72. AGN, México.

24 "Incrementamos relaciones fílmicas con Cuba", Cine Mundial, 4 de mayo de 1976. Estas películas serían las costosas producciones El recurso del método (Miguel Littín, 1977) y Mina, vientos de libertad (Antonio Eceiza, 1976). 
sor derrotado, el emperador fusilado y la república restaurada, Benito Juárez (Jorge Martínez de Hoyos) mira al horizonte y pronuncia un discurso que llamó la atención de la crítica por anacrónico y descontextualizado. En su monólogo, el héroe de la patria alerta sobre la amenaza que se ciñe sobre los pueblos colonizados y explotados por las potencias imperialistas que, sedientas siempre de los recursos de sus antiguos territorios, no cesarán en sus intentos de continuar el saqueo colonial.

Esta primera incursión mexicana en el tercermundismo fílmico resultó en un rotundo fracaso ante la crítica y en la taquilla. ${ }^{25}$ Es verdad que desde principios de los sesenta habían surgido en varios países cintas comerciales que, haciendo eco de un tercermundismo generalizado, intentaban subvertir la imagen que el cine clásico había construido del colonialismo y que la estrategia de criticar la voracidad económica de las potencias mundiales del siglo XX mediante la filmación de episodios históricos del siglo xIX había dado lugar a obras maestras como Queimada (Gillo Pontecorvo, 1969) o Caliche sangriento (Helvio Soto, 1969). ${ }^{26}$ El problema era que en Aquellos años las alegorías eran tan obvias que, a los ojos de la crítica, resultaron burdas: mezclando en los acartonados discursos de Juárez las famosas frases del liberalismo mexicano con una serie de confusas referencias al imperialismo, la cinta intentaba colocar al gobierno de México como el único capaz de detener el saqueo imperialista sobre los pueblos de Latinoamérica. ${ }^{27}$

Aunque la imperfección de esta cinta la colocó como ejemplo de las fallas del proyecto fílmico tercermundista, Aquellos años no fue un caso único $y$, justo es decirlo, su mala manufactura tampoco es completamente representativa del conjunto de obras que se realizaron con este enfoque durante el echeverrismo. La cinta sería sólo el inicio de una larga (y en algunos casos exitosa) apuesta del cine mexicano por sumarse al lado del régimen que la patrocinaba en la amplia y heterogénea corriente del cine del Tercer Mundo. Como parte

${ }^{25}$ En entrevista, el director Felipe Cazals, férreo crítico de su propia cinta recuerda: "la verdad estaba cabrón, y yo se lo dije a Fuentes. Nos pidieron que metiéramos todo en una sola película. En dos horas tenías que meter no sólo a todos los héroes de la patria, sino a toda la tradición liberal del país y, para acabarla, a todo el Tercer Mundo". Entrevista de Israel Rodríguez a Felipe Cazals, Ciudad de México, 2 de febrero de 2018.

${ }^{26}$ Agradezco al doctor Bernd Hausberger por haber llamado mi atención sobre la forma en que el tercermundismo permeó la producción de cine industrial durante las décadas de los sesenta y setenta. Para una revisión de esta influencia, véase por ejemplo el extraordinario texto de Christopher Robé (2014).

${ }^{27}$ Una revisión detallada de esta cinta en Pascual Gutiérrez (2016, pp. 32-35; 2020, cap. IV). 
de este impulso, entre 1972 y 1976, la industria fílmica mexicana, cada vez más controlada por el gobierno, produjo decenas de obras con este sello. Además de las producciones documentales del CPC, que no dejaron de acompañar las giras internacionales del presidente y de ser promocionadas por las embajadas mexicanas, el cine industrial de ficción se enfocó ampliamente en la filmación de obras fuertemente latinoamericanistas y comenzó a producir y coproducir cintas cuyas imágenes y diálogos reproducían el discurso oficial y la retórica e imágenes del cine sudamericano. A la ya mencionada Actas de Marusia podríamos sumar, por sólo mencionar los ejemplos más claros, Cananea (1976), en la que Marcela Fernández Violante hace énfasis en la voracidad de los empresarios extranjeros dispuestos a todo con tal de continuar con la explotación de los territorios latinoamericanos; la coproducción cubana Mina, viento de libertad (Antonio Eceiza, 1976), en la que un estoico Ernesto Alonso personifica al legendario insurgente español que una y otra vez lanza arengas contra la dominación colonial; o, quizá el caso más emblemático de lo que podríamos llamar un tercermundismo recalcitrante, La casa del sur (Sergio Olhovich, 1976), cinta que muestra la forma en que una comunidad del desierto emprende un viaje geográfico y temporal por todas y cada una de las etapas del colonialismo y el despojo que han sufrido las comunidades latinoamericanas.

Aunque las alegorías latinoamericanistas y tercermundistas resultaban ya evidentes en las cintas, en la mayoría de los casos no era necesario un análisis muy profundo para encontrar estos referentes, pues era frecuente que en la promoción de las cintas se dejara clara la idea central de las películas y su posicionamiento decidido al lado de la postura oficial. Hacia el final del sexenio echeverrista la euforia tercermundista del cine mexicano inundaba ya todos los espacios. Directores, guionistas, actores y técnicos, todos repetían constantemente que su participación en las distintas producciones no era una cuestión de trabajo, sino un acto de congruencia política. Incluso publicaciones como Cinelandia, antes dedicadas a anunciar estrenos o a ventilar la vida privada de las actrices, reproducían esta retórica. En entrevista con este medio, por ejemplo, la joven Patricia Reyes Espíndola, actriz secundaria del filme Actas de Marusia, declaraba que su participación en aquella cinta "me ha despertado la conciencia política; me ha sacudido ese aburguesamiento en el que yo vivía" ${ }^{28}$ En el caso de La casa del sur, por ejemplo, el propio director

28 "Intervenir en Actas de Marusia ha sido importante y determinante para la actriz y para mi persona”, Cinelandia, 431, 3 de abril de 1976. 
repitió una y otra vez que el tema central de su obra era la problemática social, política y económica de la mayoría de los pueblos latinoamericanos. Como señaló de manera burlona Carlos Monsiváis (1975, p. VIII), por aquellos días, en el cine mexicano, "al ritmo del Estado todos se apresuraron a dejarse ver como antiburgueses y revolucionarios".

Al final del gobierno echeverrista, el cine mexicano parecía monotemático y lucía como el más tercermundista del continente. Las páginas de sus revistas se llenaban con entrevistas a los cineastas o teóricos latinoamericanos, como Carlos Álvarez, Jorge Sanjinés o Julio García Espinoza; los directores de cine identificados con la izquierda cinematográfica mundial, como Glauber Rocha, Constantin Costa-Gavras o Santiago Álvarez, desfilaban uno a uno por las oficinas cinematográficas mexicanas o asistían a magnas comidas organizadas en la residencia del presidente mientras anunciaban a los medios de comunicación el beneplácito de ver cómo la industria mexicana se sumaba al movimiento internacional del cine de liberación. ${ }^{29}$

Sin embargo, como denunció una y otra vez el crítico cinematográfico Jorge Ayala Blanco (1986, passim), y como analizó tempranamente Ruy Sánchez (1981, pp. 96 y ss.), el común denominador de estas películas y de esta retórica era que lograban conciliar en sus imágenes y en sus discursos las consignas de liberación anticolonial con los postulados oficiales de un Estado mexicano que se esforzaba por apropiarse del discurso tercermundista para insertarlo como parte de la historia de su propia revolución institucional. Como lo hizo en tantos otros espacios, con esta compleja retórica de oficialismo tercermundista el cine estatal mexicano logró incorporar en sus obras los planteamientos y las preocupaciones de la nueva izquierda surgida hacia finales de los sesenta, mientras ayudaba a reconstituir la hegemonía política del régimen priista.

Al final del camino la inversión mexicana rindió indudablemente sus frutos. La incipiente colaboración con Chile Films y la acogida y promoción del cineasta exiliado Miguel Littín, por un lado, y el intenso programa de colaboración emprendido con el gobierno cubano, por el otro, lograron abrirle al cine mexicano las puertas a espacios internacionales en los que antes era prácticamente desconocido. Aunque desde los años cuarenta el cine mexicano era visto por amplios públicos de habla hispana en Latinoamérica y España,

29 "El presidente Echeverría censuró la manipulación del cine por parte de las tendencias hegemónicas”, El Nacional, 28 de junio de 1976. 
y aunque algunas de sus cintas habían alcanzado notoriedad internacional o habían conseguido importantes nominaciones, la fama y la centralidad que las producciones nacionales alcanzaron durante el periodo echeverrista fue sin duda un hecho sin precedentes. Si bien en este esfuerzo los acercamientos con las cinematografías chilena y cubana ocuparon un lugar primordial, estos no fueron los únicos espacios en los que el régimen centró sus esfuerzos por conseguir un vistoso lugar en el escenario fílmico tercermundista. También como parte de este empeño se organizaron decenas de semanas del cine mexicano en prácticamente todos los países de Sudamérica, así como en latitudes lejanas como Rusia o Argelia. No sólo eso, en algo que fue catalogado por la prensa mexicana como un despropósito, desde 1974 el BNC decidió alquilar de forma permanente la Sala Ėtoile, ubicada en la avenida Campos Elíseos, en París, para que ahí se proyectaran tanto las obras del nuevo cine mexicano como las últimas producciones africanas y latinoamericanas. La intención era llevar el nuevo cine nacional a los espacios más importantes y para lograrlo el Estado parecía no reparar en gastos. Al final, como corolario de este amplio esfuerzo y gracias a múltiples negociaciones emprendidas por Miguel Littín y por representantes del cine cubano, el Festival de Cine de Pésaro decidió dedicar en su edición de 1976 un lugar especial al proyecto fílmico echeverrista.

De este modo, hacia el final del sexenio el tercermundismo cinematográfico mexicano, al menos en términos de efectividad política, parecía todo un éxito: en el exterior, había logrado colocar a la industria estatal mexicana en el centro de espacios de debate sobre la consolidación de un movimiento de cine del Tercer Mundo; en el interior, la proyección tercermundista del cine mexicano y las relaciones diplomáticas que conllevó fueron parte de la amplia estrategia de reconciliación nacional para atraer hacia el Estado a sectores disidentes y grupos políticos que, adheridos ahora al proyecto oficial, podían enunciar libremente sus postulados revolucionarios sin representar una amenaza a la estabilidad política nacional.

Sin embargo, como es bien sabido, el tercermundismo mexicano no trascendió más allá de la administración de Echeverría. Junto a otros elementos de su proyecto político, el rumbo de la diplomacia echeverrista fue reorientado en el siguiente sexenio y volvió a cauces más tradicionales. La decisión, ciertamente, tampoco era ajena a los cambios regionales. Para la segunda mitad de los años setenta la consolidación de regímenes militares completamente afines a Estados Unidos en la mayoría de los países sudamericanos hizo fracasar cualquier intento de unidad y solidaridad latinoame- 
ricana. "Las divisiones ideológicas eventualmente fracturaron la solidaridad hemisférica y permitieron a los Estados Unidos evitar el escenario temido de una región unida contra la influencia estadounidense" (Brands, 2008). Además, las cada vez más evidentes muestras de crisis económica en los países de la región echaron por tierra los proyectos impulsados de manera conjunta y dejaron a los gobiernos del sur nuevamente a expensas de los créditos y las ayudas del aliado del norte (Brands, 2008, p. 107).

En ese contexto, como ocurrió con el proyecto político nacional del cual se desprendía, el tercermundismo cinematográfico mexicano fue breve y la firmeza de sus convicciones no soportó el cambio de sexenio. ${ }^{30}$ Aunque hacia los últimos meses de 1976 el cine mexicano redobló esfuerzos tanto por consolidar su contenido antiimperialista como por afianzar a México como referente indiscutible de la cinematografía tercermundista, ${ }^{31}$ tras el cambio de gobierno de diciembre de 1976 todo pareció esfumarse. Durante los primeros años de la administración de López Portillo, la incursión de México en la corriente tercermundista recibió fuertes críticas $-y$ no pocas burlas- y se le señaló comúnmente como la causa de la crisis por la que atravesaba el país. ${ }^{32}$ Del mismo modo, el fracaso económico del proyecto fílmico echeverrista se explicó rápidamente por el hecho de que las películas sobre temas latinoamericanos fueron las más caras y las menos exitosas de entre todas las producciones estatales. Aunque en el ámbito internacional el plan de renovación echeverrista continuó recibiendo apoyo en algunos encuentros de cineastas latinoamericanos, ${ }^{33}$ los pronunciamientos hechos en estos espacios perdieron relevancia en el interior del país y ni siquiera fueron replicados por la prensa nacional. Además, del mismo modo en que la beligerancia del tercermundismo diplomático latinoamericano había perdido casi toda su fuerza hacia

30 Tomo de A. S. Dullingham (2018, p. 114), la idea de describir este periodo como "Mexico's short-lived Third Worldist Project".

${ }^{31}$ Así, en 1976 no sólo se incrementó la producción de las cintas antes mencionadas, sino también la participación de México en importantes eventos internacionales. En ese año, por ejemplo, México consiguió ser sede de importantes congresos como las reuniones anuales de la Federación Internacional de la Prensa Cinematográfica (FIPRECI) y de la Federación Internacional de Archivos Fílmicos (FIAf), ambos presididos por el secretario de Gobernación, Moya Palencia, y albergados en la Cineteca Nacional.

${ }^{32}$ Alfredo Kawage, "El Tercer Mundo y el mundo de tercera", Siempre!, 1215, 6 de octubre de 1976 .

${ }^{33}$ El nuevo cine mexicano y su importancia para América Latina, en Por un Cine Latinoamericano, V Encuentro de Cineastas Latinoamericanos, Mérida, 27 de abril de 1977. 
finales de los años setenta (Brands, 2008, p. 107), la institucionalización del movimiento del nuevo cine latinoamericano en el festival de La Habana, en 1979, terminó con dos décadas de efervescencia política y cinematográfica en la región y dio paso a una nueva etapa mucho más mesurada.

\section{CONCLUSIONES}

Aunque el éxito o fracaso del proyecto fílmico echeverrista (con su apertura cinematográfica, su renovación de cuadros y su modernización temática) sigue siendo un tema a debate, resulta indudable que fue en la esfera internacional donde la sujeción de la industria cinematográfica al proyecto político del régimen rindió sus principales frutos. En este ámbito, gracias a un intenso trabajo diplomático y a una incansable labor de promoción y búsqueda de nuevos mercados, la industria mexicana y el régimen que la soportaba lograron posicionarse en los principales foros de la cinematografía mundial y, de manera destacada, en importantes espacios del llamado cine del Tercer Mundo. Estableciendo relaciones cinematográficas con países que en distintos momentos ocuparon lugares protagónicos dentro del tercermundismo internacional como Chile, Cuba o Argelia, recibiendo y patrocinando a cineastas exiliados por las dictaduras militares, organizando semanas de cine mexicano en lejanas ciudades de Asia y África, produciendo esquemáticas épicas antiimperialistas y protagonizando importantes festivales de cine tercermundista, el proyecto fílmico del echeverrismo logró colocar a la cinematografía mexicana en el escenario internacional y, al mismo tiempo, servirse de ella para promocionar el discurso antiimperialista del gobierno.

Además, aunque no estuvo ajena a tensiones, y aunque fue objeto de constantes críticas en las que se le denunciaba como oportunista, en términos generales el giro de la industria cinematográfica mexicana hacia el tercermundismo fue verdaderamente exitoso. Gracias a esta labor, el cine oficial mexicano no sólo llegó a públicos antes insospechados y acumuló decenas de premios y nominaciones en distintos certámenes a lo largo del mundo, sino que, dentro y fuera del país logró apropiarse de las banderas políticas y de los espacios del cine de liberación, atrayendo hacia el cine estatal a un número importante de creadores progresistas que desde el interior del proyecto oficial pudieron filmar y promover sus obras antiimperialistas sin representar una amenaza para la estabilidad política nacional. 


\section{LISTA DE REFERENCIAS}

Amaral de Aguiar, C. (2018). Pueblos hermanos: Chile en el cine del Centro de Producción de Cortometraje mexicano en la década de 1970. En M. Villarroel (comp.), Imaginarios del cine chileno y latinoamericano. Santiago de Chile: LOM.

Anguiano, E. (1977). México y el Tercer Mundo: racionalización de una posición. Foro Internacional, 18, 69.

Ayala Blanco, J. (1969). Crónica del Festival de Viña del Mar. La Cultura en México, suplemento de Siempre!, 407.

Ayala Blanco, J. (1976). Masacrofilia. La retórica de la masacre; la folclorización del sufrimiento. La Cultura en México, suplemento de Siempre!, 1193.

Ayala Blanco, J. (1986). La condición del cine mexicano. México: Posada.

Barría Troncoso, A. (2001). El espejo quebrado. Memorias del cine de Allende y la Unidad Popular. Santiago: Uqbar Editores.

Berger, M. T. (2004). After the third world? History, destiny and the fate of third worldism. Third World Quarterly, 25(1), 9-39. Recuperado de http://www.jstor.org/ stable/3993775

Brands, H. (2008). Third world politics in an age of global turmoil: The Latin American challenge to U.S. and western hegemony, 1965-1975. Diplomatic History, 32(1), 105-138. Recuperado de http://www.jstor.org/stable/24916057

Brands, H. (2010). Latin America's cold war. Cambridge: Harvard University Press.

Byrne, J. (2016). Mecca of revolution. Algeria, decolonization, and the Third World order. Nueva York: Oxford University Press.

Costa, P. (1998). La "apertura" cinematográfica: México 1970-1976. Puebla: Universidad Autónoma de Puebla.

Díaz Prieto, G. (2010). Un exilio venturoso: chilenos en México, 1973-1990. En Revolución y exilio en la historia de México: del amor de un historiador a su patria adoptiva: homenaje a Friedrich Katz. México: El Colegio de México/Ediciones Era/The Univerisity of Chicago-Centro Katz de Estudios Mexicanos.

Díaz Prieto, G. (1998). México frente a Chile. Tiempos de ruptura y exilio: 1973-1990 (Tesis de licenciatura). México, Instituto Tecnológico Autónomo de México.

Dullingham, A. S. (2018). Mexico's turn toward the Third World: Rural development under president Luis Echeverría. En J. M. Pensado y E. C. Ochoa, México beyond 1968: revolutionaries, radicals, and repression during the global sixties and subversive seventies. Tucson: The University of Arizona Press. 
Echeverría, R. (1976). Cineinforme general de la actividad cinematográfica de Banco Nacional Cinematográfico S. A. y sus filiales. México: Banco Nacional Cinematográfico.

Elena, A. (1993). El cine del Tercer Mundo: diccionario de realizadores. Madrid: Turfan.

García Borrero, J. A. (2008). "Cine cubano post 68”. Conferencia leída por su autor, el 2 de septiembre del 2008 en el Centro Teórico Cultural Criterios (La Habana), como parte del ciclo "La política cultural del período revolucionario: memoria y reflexión”, organizado por dicho Centro. Recuperado de https://ufsinfronteradotcom.files.wordpress.com/2011/04/juan-antonio-garcia-borrero-cine-cubano-post68.pdf

García Robles, A. (1976). Seis años de la política exterior de México, 1970-1976. México: Secretaría de Relaciones Exteriores.

Harmer, T. (2013). Two, three, many revolutions? Cuba and the prospects for revolutionary change in Latin America, 1967-1975. Journal of Latin American Studies, 45(1). DoI: https://doi.org/10.1017/S0022216X1200123X

Herrera, O. y Santa Cruz, A. (2010). Historia de las relaciones internacionales de México, 1821-2010 (vol. 1: América del Norte). México: Secretaría de Relaciones Exteriores.

Kalter, C. (2013). A shared space of imagination, communication, and action: Perspectives on the history of the "Third World". En S. Christiansen y Z. A. Scarlett (eds.), The Third World in the global 1960s. Nueva York: Berghahn Books.

Kalter, C. (2016). The discovery of the Third World: Decolonization and the rise of the new left in France, c. 1950-1976. Cambridge: Cambridge University Press.

Keller, R. (2015). Mexico's cold war: Cuba, the United States, and the legacy of the Mexican revolution. Nueva York: Cambridge University Press.

Lajous, R. (2012). Historia mínima de las relaciones exteriores de México, 1821-2000. México: El Colegio de México.

Loaeza, S. (2013). Estados Unidos y la contención del comunismo en América Latina y en México. Foro Internacional, 53(1). Recuperado de https://link.gale.com/apps/ doc/A391109147/IFME?u=anon 9c028dbb\&sid=googleScholar\&xid=90afd 890

Márquez, G. y Sergio S. (2014). Auge y decadencia de un proyecto industrializador (1954-1982). En Claves de la historia económica de México: el desempeño de largo plazo (siglos XVI-XXI). México: Fondo de Cultura Económica/Dirección General de Publicaciones-Consejo Nacional para la Cultura y las Artes.

Mestman, M. (2008). Entre Argel y Buenos Aires: el Comité de Cine del Tercer Mundo (1973/1974). La Fuga, 6. Recuperado de http://2016.lafuga.cl/entre-argely-buenos-aires $/ 28$

Mestman, M. (ed.) (2015). Estados generales del Tercer Cine. Los documentos de Montreal, Buenos Aires: Prometeo. 
Mestman, M. (2016). Presentación. Las rupturas del 68 en el cine de América Latina. Contracultura, experimentación y política. En M. Mestman (comp.), Las rupturas del 68 en el cine de América Latina: contracultura, experimentación y política. Buenos Aires: Akal.

Mestman, M. (2017). Argel, Buenos Aires, Montreal: el Comité de Cine del Tercer Mundo (1973 / 1974). Secuencias, 43-44, 73-93. Dor: https://doi.org/10.15366/ secuencias2016.43-44.005

Monsiváis, C. (1975). Fallaste Corazón. Cine mexicano: y tú que te creías el rey de todo el mundo. La Cultura en México, suplemento de Siempre!, 1142.

Ojeda, M. (1977). México ante los Estados Unidos en la coyuntura actual. Foro Internacional, 18(1), 32-51. Recuperado de https://forointernacional.colmex.mx/index. $\mathrm{php} /$ fi/article/view/759

Ojeda, M. (2001). Alcances y límites de la política exterior de México. México: Centro de Estudios Internacionales-El Colegio de México.

Pascual Gutiérrez, I. (2016). La reformulación del autoritarismo mexicano durante la presidencia de Luis Echeverría (1970-1976). La política cinematográfica como ejemplo. Millars: Espai i Historia, 41(2). Recuperado de http://www.e-revistes.uji. es/index.php/millars/article/view/3234

Pascual Gutiérrez, I. (2020). Invocando el pasado: cine histórico y Estado en México (19711976). La Rioja: Universidad Internacional de la Rioja.

Pelayo, A. (2016). Una nueva política cinematográfica durante el sexenio de Luis Echeverría. En A. de los Reyes (comp.), Miradas al cine mexicano. México: Secretaría de Cultura/Instituto Mexicano de Cinematografía.

Pellicer, O. (1972). Cambios recientes en la política exterior mexicana. Foro Internacional, 13(2). Recuperado de https://forointernacional.colmex.mx/index.php/fi/ article/view $/ 558$

Pellicer, O. (1975). Tercermundismo del capitalismo mexicano: ideología y realidad. Cuadernos Políticos, 3, 52-59. Recuperado de http://www.cuadernospoliticos.unam. $\mathrm{mx} /$ cuadernos/num03.html

Pérez Turrent, T. (1974). La semana del cine cubano. Sucesos para Todos, 2165.

Pettinà, V. (2015). Global horizons: Mexico, the Third World, and the non-aligned movement at the time of the 1961 Belgrade conference. The International History Review, 38(4), 741-764. DoI: https://doi.org/10.1080/07075332.2015.1124906

Prashad, V. (2007). The darker nations. A people's history of the Third World. Nueva York: New Press. 
Robé, C. (2014). When cultures collide: Third cinema meets the Spaghetti Western. Journal of Popular Film and Television, 42(3), 163-174. Dor: https://doi.org/10.1080/ 01956051.2014.881770

Rodríguez, I. (2020). Del nacionalismo al tercermundismo. El itinerario mexicano de Miguel Littín. Estudios del ISHIR, 10(28). Recuperado de https://web3.rosario-conicet.gov.ar/ojs/index.php/revistaISHIR/article/view/1322

Rodríguez, I. (en prensa). Renovación fílmica y autoritarismo en México, 1970-1976. Revisión a la idea del Estado cineasta. Historia y Grafía, 58(31).

Rojas Mira, C. F. (2016). Los anfitriones del exilio chileno en México, 1973-1993. Historia Crítica, 60, 123-140. Dor: https://doi.org/10.7440/histcrit60.2016.07

Ruy Sánchez, A. (1981). Mitologías de un cine en crisis. México: Premia.

Salazar Navarro, S. (2020). Cine, revolución y resistencia. La política cultural del Instituto Cubano del Arte e Industria Cinematográficos hacia América Latina. Pittsburgh: Latin America Research Commons.

Shapira, Y. (1978). La política exterior de México bajo el régimen de Echeverría: retrospectiva. Foro Internacional, 19(1). DoI: https://doi.org/10.24201/fi.v19i1.788

Sousa de Silva, A. de (2015). A filmografia de Miguel Littín entre o exílio e a clandestinidade (1973-1990). (Tesis de maestría). Brasil, Universidade de São Paulo.

Valero, R. (1972). La política exterior de México en la coyuntura actual. Foro Internacional, 13(2). Recuperado de https://forointernacional.colmex.mx/index.php/fi/ issue/view/48

Valle Dávila, I. del (2012). Hacia un tercer cine: del manifiesto al palimpsesto. El Ojo que Piensa. Revista de Cine Iberoamericano, 3(6). Recuperado de http://www.elojoquepiensa.cucsh.udg.mx/index.php/elojoquepiensa/article/view/79

Vázquez Mantecón, Á. (2016). El 68 cinematográfico. En M. Mestman (comp.), Las rupturas del 68 en el cine de América Latina. Buenos Aires: Akal.

Vega, S. et al. (2007). Historia de un gran amor: relaciones cinematográficas entre Cuba y México 1897-2005. La Habana/Guadalajara: Instituto Cubano de Arte e Industria Cinematográficos/Cinemateca Cubana/Universidad de Guadalajara/Centro Universitario de Ciencias Sociales y Humanidades.

Willemen, P. (1989). The third cinema question: Notes and reflections. En Questions of third cinema. Londres: British Film Institute.

Wright, T. C. (2018). Latin America in the era of Cuban revolution. Santa Barbara: Praeger. 


\section{OTRAS FUENTES}

\section{Archivos}

AGN Archivo General de la Nación, México.

Centro de Documentación de la Cineteca Nacional, México.

Cinemateca de Cuba, La Habana.

\section{Hemerografía}

Cinelandia, 1976.

Cine Mundial, 1976.

El Día, 1974.

El Nacional, 1976.

Excélsior, 1976.

Juventud Rebelde, 1974.

Siempre!, 1974, 1976.

Sucesos para Todos, 1974. 